\begin{tabular}{|c|c|}
\hline Title & Genotyping of sand fly species in Peruvian A ndes where leishmaniasis is endemic \\
\hline Author(s) & $\begin{array}{l}\text { Fujita, Megumi; Kato, Hirotomo; Cáceres, A braham G.; Gomez, Eduardo A .; V elez, Lenin; Mimori, T atsuyuki; Zhang, } \\
\text { Feifei; Iwata, Hiroyuki; Korenaga, Masataka; Sakurai, T atsuya; Katakura, Ken; Hashiguchi, Y oshihisa }\end{array}$ \\
\hline Citation & $\begin{array}{l}\text { A cta T ropica, 121(2), 93-98 } \\
\text { https://doi.org/10.1016/.actatropica.2011.10.004 }\end{array}$ \\
\hline Issue Date & $2012-02$ \\
\hline Doc URL & http:/hdl.handle.net/2115/48545 \\
\hline Tyре & article (author version) \\
\hline File Information & AT121-2_93-98.pdf \\
\hline
\end{tabular}

Instructions for use 


\section{Genotyping of sand fly species in Peruvian Andes where leishmaniasis is endemic}

Megumi Fujita ${ }^{\mathrm{a}}$, Hirotomo Kato ${ }^{\mathrm{a}, \mathrm{b}}{ }_{*}$, Abraham G. Cáceres $^{\mathrm{c}, \mathrm{d}}$, Eduardo A. Gomez ${ }^{\mathrm{e}}$, Tatsuyuki Mimori ${ }^{\mathrm{f}}$, Feifei Zhang ${ }^{\mathrm{b}}$, Hiroyuki Iwata ${ }^{\mathrm{a}}$, Masataka Korenaga ${ }^{\mathrm{g}}$, Tatsuya Sakurai $^{\text {b }}$, Ken Katakura ${ }^{\text {b }}$, Yoshihisa Hashiguchi ${ }^{\mathrm{g}}$

${ }^{a}$ Laboratory of Veterinary Hygiene, Faculty of Agriculture, Yamaguchi University, Yamaguchi, Japan, ${ }^{\mathrm{L}}$ Laboratory of Parasitology, Department of Disease Control, Graduate School of Veterinary Medicine, Hokkaido University, Sapporo, Japan, cDepartamento Académico de Microbiología Médica, Facultad de Medicina Humana, Universidad Nacional Mayor de San Marcos, Lima, Peru, ${ }^{\mathrm{d}}$ Laboratorio de Entomología, Instituto Nacional de Salud, Lima, Peru, ${ }^{\mathrm{e}}$ Programa de Oncocercosis, Servicio Nacional de Erradicacion de la Malaria (SNEM), Ministerio de Salud Publica, Ecuador, ${ }^{\mathrm{f}}$ Department of Microbiology, Faculty of Life Sciences, Graduate School of Health Sciences, Kumamoto University, Kumamoto, Japan, ${ }^{\mathrm{g}}$ Department of Parasitology, Kochi Medical School, Kochi University, Kochi, Japan.

*Corresponding author at: Laboratory of Parasitology, Department of Disease Control, Graduate School of Veterinary Medicine, Hokkaido University, North 18 West 9, Kita-ku, Sapporo, Hokkaido, 060-0818, Japan.

Phone \& Fax: +81-11-706-5196.

E-mail address: hkato@vetmed.hokudai.ac.jp (H. Kato). 


\begin{abstract}
Genotyping of sand fly species circulating in Peru was established on the basis of PCR-restriction fragment length polymorphisms (RFLPs) of the $18 \mathrm{~S}$ ribosomal RNA (rRNA) gene. The sequences of 18S rRNA gene fragments from 12 Lutzomyia and 1 Warileya species were determined and their RFLP-patterns were analyzed. Consequently, RFLP analysis with the restriction enzyme AfaI and then HapII or KpnI, followed by $X s p$ I successfully differentiated them. Intraspecific genetic diversity affecting RFLP-patterns was not detected in the specimens collected from 24 areas of 8 departments. The genotyping was applied to the surveillance of sand flies collected from Andean areas where leishmaniasis is endemic, and its usability was verified. The present method promises to be a powerful tool for the classification and surveillance of sand flies circulating in Peru.
\end{abstract}

Keywords: genotyping, sand fly, Lutzomyia, PCR-RFLP, 18S rRNA gene 


\section{Introduction}

Phlebotomine sand flies are insects of the family Psychodidae in the order Diptera, and approximately 800 species have been recorded in five major genera; Phlebotomus and Sergentomyia in the Old World, and Lutzomyia, Brumptomyia and Warileya in the New World (Munstermann, 2004). The majority of the species play no part in the transmission of human pathogens. However, some species belonging to the genera Phlebotomus and Lutzomyia have been identified as vectors of leishmaniasis, though each vector can transmit only certain species of Leishmania (Munstermann, 2004; Bates, 2007; Kato et al., 2010a). Since the spread of leishmaniasis largely depends on the distribution of the vector species, the identification of circulating sand flies in endemic and surrounding areas is important for predictions of the risk and expansion of the disease. Sand flies are typically identified based on morphologic characteristics; mainly internal structures such as the cibarium, pharynx, spermatheca of females and terminal genitalia of males (Young and Duncan, 1994). Morphological classification requires considerable skill and taxonomic expertise, and has the potential risk of misidentification. To overcome these problems, molecular markers have been explored to develop easier and accurate ways of classifying sand flies, and most results of DNA sequence analyses support the morphology-based grouping (Aransay et al., 1999; Torgerson et al., 2003; Beati et al., 2004; Kato et al., 2007, 2008; Terayama et al., 2008; Kuwahara et al., 2009; Cohnstaedt et al., 2011). Since a DNA sequence analysis requires no special storage conditions for samples and less expertise with minimum risk of different interpretations among researchers, the usability of this method for sand fly taxonomy is now widely accepted (Kato et al., 2010a).

Recently, we developed a genotyping method to classify 7 sand fly species 
distributed in Ecuador by using a PCR-restriction fragment length polymorphism (RFLP) analysis of 18S rRNA genes (Terayama et al., 2008). The procedure was applied successfully to the differentiation of 3 sand fly species in Peru (Kato et al., 2008). In Peru, approximately 160 species of Phlebotomine sand flies have been reported, most of which were recorded from Eastern Valleys and Amazonian regions (Caceres and Galati, 2001). In the present study, to further advance this technique for countrywide surveillance in Peru, a PCR-RFLP assay of the 18S rRNA gene was optimized for the differentiation of 13 species, mainly distributing in Andean areas, and applied to the surveillance of sand flies in Andean areas of Peru where cutaneous leishmaniasis caused by Leishmania (Viannia) peruviana is endemic. 


\section{Materials and methods}

\subsection{Sand fly collection}

Sand flies were collected with CDC light traps and Shannon traps peridomiciliary and/or extradomiciliary in an Amazonian area, Tarapoto, Department of San Martin, and 23 Andean areas of Peru; San Ignacio, Coro Alto, La Capilla, Chota, San Miguel and Santa Cruz de Toledo, Department of Cajamarca; Chanchamayo, La Cuesta, Nambuque and Padregual, Department of La Libertad; San Pedro de Chonta, Department of Huanuco; Colcap Bajo, Curcuy, Huanchoc, Atocshay and Pucuhuayllan, Department of Ancash; Ambar, Jalcan and Huacan, Department of Lima; Higosniyocc and Pullo, Department of Ayacucho; and Ocobamba and Maranura, Department of Cusco (Fig. 1). All the flies were captured throughout the night between 18:00 p.m. and 6:00 a.m. with CDC light traps and between 18:00 p.m. and 22:00 p.m. with Shannon traps. The sand flies were morphologically identified based on measurements of wing veins, the ratio of length of palpus to length of antenna and the color of the thorax (Young and Duncan, 1994), and then fixed in 70\% ethanol. The species and number of sand flies subjected to the PCR-RFLP analyses for assessing genetic variation at each collection site are shown in Fig. 1. For the large-scale field surveillance of prevalent species, sand flies were captured with CDC light traps and Shannon traps in 11 Andean areas; Loma Grande, La Cuesta, Nambuque and Padregual, Department of La Libertad; Atocshay, Colcap Bajo, Curcuy, Huanchoc and Pucuhuayllan, Department of Ancash; and Ambar and Huarochiri, Department of Lima. The sand flies were fixed in $70 \%$ ethanol and stored at room temperature. 


\subsection{DNA extraction}

Ethanol-fixed specimens were individually lysed in $50 \mu \mathrm{l}$ of DNA extraction buffer [150 mM NaCl, $10 \mathrm{mM}$ Tris-HCl (pH 8.0), $10 \mathrm{mM}$ EDTA and $0.1 \%$ sodium dodecyl sulfate $(\mathrm{SDS})]$ in the presence of proteinase $\mathrm{K}(100 \mu \mathrm{g} / \mathrm{ml})$. The samples were incubated overnight at $37^{\circ} \mathrm{C}$, and 0.5 - $\mu$ l portions were directly used as templates for PCR amplification without purification (Kato et al., 2007, 2008).

\subsection{Molecular cloning and nucleotide sequencing}

The amplification of $18 \mathrm{~S}$ rRNA gene fragments was performed with sand fly $18 \mathrm{~S}$ rRNA gene-specific primers (Lu.18S 1S: 5'-TGCCAGTAGTTATATGCTTG-3' and Lu.18S AR: 5'-CACCTACGGAAACCTTGTTAC-3') (Terayama et al., 2008; Kato et al., 2007, 2008). The PCR was carried out in a volume of $15 \mu 1$ with the primers $(0.4$ $\mu \mathrm{M}$ each), Ampdirect Plus (Shimadzu Biotech, Tsukuba, Japan), and Taq polymerase (Ex Taq; Takara Bio, Shiga, Japan). After an initial denaturation at $95^{\circ} \mathrm{C}$ for $5 \mathrm{~min}$, the amplification was performed with 40 cycles of denaturation $\left(95^{\circ} \mathrm{C}, 1 \mathrm{~min}\right)$, annealing $\left(50^{\circ} \mathrm{C}, 1 \mathrm{~min}\right)$ and polymerization $\left(72^{\circ} \mathrm{C}, 2 \mathrm{~min}\right)$, followed by a final extension at $72^{\circ} \mathrm{C}$ for $10 \mathrm{~min}$. The PCR products were directly cloned into the plasmid using a pGEM-T Easy Vector System (Promega, Madison, WI), and plasmid DNA was extracted with a QIAprep Spin Miniprep Kit (QIAGEN, Hamburg, Germany). The inserts of the plasmids were sequenced by the dideoxy chain termination method using a BigDye Terminator v3.1 Cycle Sequencing Kit (Applied Biosystems, Foster City, CA).

\subsection{Phylogenetic analysis}


The sequences obtained were aligned with CLUSTAL W software (Thompson et al., 1994) and examined using the program MEGA (Molecular Evolutionary Genetics Analysis) version 4.0 (Tamura et al., 2007). Phylogenetic trees were constructed by the neighbor-joining method with the distance algorithms in the MEGA package. Bootstrap values were determined with 1,000 replicates of the data sets.

\subsection{Restriction fragment analysis}

Each PCR product was digested with the restriction enzyme, AfaI, HapII, KpnI or XspI (Takara Bio). The digested samples were separated by electrophoresis in a 2 or $3 \%$ agarose gel to produce DNA fragments. 


\section{Results}

\subsection{Sequence analyses of the sand fly $18 S$ rRNA gene}

To establish a PCR-RFLP-based method of genotyping sand fly species circulating in Peru, 18S rRNA gene sequences were determined in 13 species, Lutzomyia (Lu.) caballeroi, Lu. castanea, Lu. munaypata, Lu. noguchii, Lu. nuneztovari, Lu. ayacuchensis, Lu. peruensis, Lu. nevesi, Lu. robusta, Lu. maranonensis, Lu. verrucarum, Lu. tejadai and Warileya (W.) phlebotomanica. The DNA inserts were 1,965-2,048bp long and showed $92 \%$ or greater homology with the 18S rRNA sequences recorded for each of the Lutzomyia species registered in GenBank. The nucleotide sequence data are available in the DDBJ/EMBL/GenBank databases under the accession numbers AB638299-AB638311. A phylogenetic analysis was performed on the newly determined $18 \mathrm{~S}$ rRNA gene sequences to observe the relationships among species. As shown in Fig. 2, most species that belonged to the same subgenus (Young and Duncan, 1994; Beati et al., 2004) were located in the same cluster; that is, Lu. caballeroi, Lu. castanea, Lu. tejadai, Lu. munaypata, Lu. ayacuchensis, Lu. peruensis and Lu. noguchii composed a clade of the subgenus Helcocyrtomyia whereas $L u$. robusta, Lu. maranonensis and Lu. nevesi made up another clade of the subgenus Pifanomyia (Fig. 2). On the other hand, two Verrucarum group species, Lu. nuneztovari and Lu. verrucarum, were located in a clade of the subgenus Helcocyrtomyia and subgenus Pifanomyia, respectively (Fig. 2). Warileya phlebotomanica was positioned in a separate branch from Lutzomyia species (Fig. 2).

\subsection{Genotyping of sand fly species}


The restriction fragment patterns of the 18S rRNA gene fragments from 13 sand fly species were examined by using GENETYX software (GENETYX CORPORATION, Tokyo, Japan), and a RFLP analysis with the restriction enzyme $A f a \mathrm{I}$ and then HapII or $K p n I$, followed by XspI was expected to differentiate them (Fig. 3A). Two closely related species, Lu. caballeroi and Lu. castanea, were indistinguishable (Fig. 3A). Then, the genotyping of 13 morphologically identified sand fly species was performed by RFLP analysis of the 18S rRNA gene using AfaI, HapII, KpnI and XspI. When digested with AfaI, Lu. maranonensis, Lu. verrucarum, Lu. tejadai and $W$. phlebotomanica showed unique RFLP-patterns, but Lu. caballeroi, Lu. castanea, Lu. munaypata, Lu. noguchii and Lu. nuneztovari were not distinguishable from each other on the gel (Fig. 3B). Similarly, Lu. ayacuchensis and Lu. peruensis as well as $L u$. robusta and Lu. nevesi showed indistinctive RFLP-patterns (Fig. 3B). HapII-digestion divided Lu. caballeroi, Lu. castanea, Lu. munaypata, Lu. noguchii and Lu. nuneztovari into two groups, one comprising Lu. caballeroi and Lu. castanea, and the other, Lu. munaypata, Lu. noguchii and Lu. nuneztovari (Fig. 3C). In addition, XspI-digestion of the latter three species gave species-specific RFLP-patterns (Fig. 3D). On the other hand, Lu. ayacuchensis and Lu. peruensis were distinguished by KpnI-digestion (Fig. 3E), and Lu. robusta and Lu. nevesi by HapII-digestion (Fig. 3C). Two closely related species, $L u$. caballeroi and $L u$. castanea, were indistinguishable by the present genotyping targeting the $18 \mathrm{~S}$ rRNA gene. The genotyping was performed on morphologically-identified sand flies captured at different sites in Peru to examine if genetic diversity affecting RFLP-patterns was evident. To this end, 3 of Lu. castanea, 2 of Lu. munaypata, 2 of Lu. nuneztovari, 2 of Lu. tejada, 2 of Lu. nevesi, and 3 of $L u$. robusta, each from one area, 13 of $\mathrm{Lu}$. caballeroi and 7 of $\mathrm{Lu}$. maranonensis, both 
from 2 areas, 7 of Lu. ayacuchensis from 3 areas, 9 of Lu. noguchii from 4 areas, 28 of Lu. verrucarum from 9 areas, 38 of $L u$. peruensis from 10 areas, and 6 of $W$. phlebotomanica from 2 areas were tested (Fig. 1). No genetic diversity affecting the RFLP-patterns obtained with $A f a \mathrm{I}$, HapII, KpnI or XspI-digestion was observed within each of the 13 species.

The present genotyping was applied to the surveillance of sand flies in 4 northern and 7 central Andean areas where leishmaniasis mainly caused by $L$. (V.) peruviana is endemic. A total of 1,240 sand flies were examined, and dominant species were identified as Lu. peruensis and Lu. caballeroi in the northern areas, and Lu. verrucarum and $L u$. peruensis in the central Andes (Table 1). Although the genotyping cannot differentiate between $L u$. caballeroi and Lu. castanea, the sand flies captured in Nambuque and Padregual, Department of La Libertad were classified as Lu. caballeroi on the basis of their distribution (Kato et al., 2011). The distribution of Lu. peruensis, a main vector species of $L$. (V.) peruviana in the Peruvian Andes (Perez et al., 1991, 1994, 2007; Kato et al., 2008, 2011), was verified in 10 of the 11 endemic areas surveyed. Intraspecific genetic diversity affecting the RFLP-patterns was not observed. 


\section{Discussion}

Previously, 3 sand fly species, Lu. verrucarum, Lu. peruensis and Lu. noguchii, from the Peruvian Andes were successfully classified by a simple PCR-RFLP-based genotyping (Kato et al., 2008). In the present study, the technique was further applied to the countrywide surveillance of sand flies circulating in the Peruvian Andes. The 18S rRNA gene sequences of 13 sand fly species were determined, and PCR-RFLP analyses of the gene fragments with $A f a \mathrm{I}, H a p I I, K p n I$ and XspI enzymes successfully differentiated the species from 24 endemic areas in the absence of intraspecific genetic diversity affecting the RFLP-patterns. The usability of the present genotyping was confirmed through its application to large-scale surveillance in Andean areas endemic for cutaneous leishmaniasis caused by L. (V.) peruviana.

A phylogenetic analysis of 12 Lutzomyia and 1 Warileya species isolated in this study was performed to observe the relationships among species. Most of the results supported the generally accepted classification based on morphological characteristics (Young and Duncan, 1994); however, Lu. nuneztovari and Lu. verrucarum, both of which belong to the Verrucarum group, were closely associated with subgenus Helcocyrtomyia and Pifanomyia species, respectively, in the analysis (Fig. 2). A similar observation indicating that $L u$. nuneztovari from Bolivia was located in the Helcocyrtomyia clade was made on the basis of the 18S rRNA gene sequence (Terayama et al., 2008). In addition, a discrepancy in the classification of Lutzomyia species including the Verrucarum group between the morphological examination and phylogenetic analyses of $12 \mathrm{~S}$ and $28 \mathrm{~S}$ rRNA gene sequences was reported (Beati et al., 2004), suggesting the necessity for careful reconsideration of the classification of some Lutzomyia species. Further DNA sequence analyses targeting rRNA internal 
transcribed spacer (ITS) regions and the mitochondrial cytochrome $b$ gene may help to clarify the issue.

In the present study, a RFLP analysis using restriction enzymes, AfaI, HapII, KpnI and $X s p I$, successfully differentiated the species although two closely-related species, Lu. caballeroi and Lu. castanea, were indistinguishable. The present method may seem not to be simple; however, information on the distributions of sand fly species in each area is accumulating. Besides, not many species usually coexist in an area. Therefore, only a few steps will be required for actual field surveillance. In addition, modification of the sampling method can restrict the species captured since the use of light traps usually results in the collection of more species including non-human biting species and cold-blood feeders when compared to the use of protected human bait.

On assessment of the genetic diversity affecting RFLP-patterns in sand flies collected from 24 endemic areas of 8 departments in the Peruvian Andes, no intraspecific variation was observed in the present 13 species although it was reported in several other species (Aransay et al., 1999; Terayama et al., 2008). Further study will be required to clarify the genetic diversity within each sand fly species; however, the 18S rRNA gene of Peruvian species seems to have less DNA polymorphism and therefore would be a suitable target for genotyping.

The present method was applied to the surveillance of sand flies in 4 northern and 7 central Andean areas where cutaneous leishmaniasis caused by $L .(V$.) peruviana is endemic. Consistent with previous reports and the present morphological examination, $L u$. peruensis and $L u$. caballeroi were identified as two dominant species in northern Andean areas, especially in Nambuque and Padregual, whereas $L u$. verrucarum and Lu. peruensis were identified as major species in central Andes (Kato et 
al., 2008, 2011). No intraspecific genetic diversity affecting RFLP-pattern was detected in the present 1,240 specimens. Lutzomyia peruensis known as a main vector species of L. (V.) peruviana (Perez et al., 1991, 1994, 2007; Kato et al., 2008, 2011) was identified in most areas, suggesting that this species is associated with the disease transmission in these areas. Lutzomyia verrucarum, which was identified as a dominant species in central Andes, was reported to exhibit a capacity for transmission of L. (V.) peruviana under experimental conditions (Davies et al., 1993). Therefore, possible transmission of the disease by this species may be considered in the areas where Lu. verrucarum is prevalent. Lutzomyia ayacuchensis, another proven vector of $L$. (V.) peruviana in the western Andean valleys of the Department of Ayacucho (Caceres et al., 2004), was not identified in the present study.

In conclusion, a PCR-RFLP-based method for genotyping sand fly species was established, and its usability was verified through its application to field surveillance in 11 Andean areas where cutaneous leishmaniasis is endemic. Since the incidence and expansion of leishmaniasis is associated with the distribution of vectors, periodical large-scale surveillance of prevalent sand flies in various endemic areas in different seasons using the present simple genotyping will provide information helpful for the control of vectors and disease expansion. In addition, combined application of the present genotyping with a recently established molecular mass screening for Leishmania-infected sand flies (Kato et al., 2007, 2008) will be a powerful tool for the investigation of individual sand flies in each endemic area. Finally, further DNA sequence analyses of sand flies will advance a definitive PCR-RFLP-based molecular taxonomy as well as the molecular evolutionary analysis of sand fly species. 


\section{Acknowledgements}

We are indebted to Flavio-Valeriano Zambrano C. (Servicio Nacional de Erradicacion de la Malaria, Guayaquil, Ecuador), Roberto Sud A. (Ministerio de Salud Publica y Asistencia Social, Guayaquil, Ecuador), Faustino Carbajal C. (DESA La Libertad, Trujillo, Peru) and Liz Jesenia Espejo A. (Escuela de Biologia, Facultad de Ciencias Naturales y Matematica, Universidad Nacional Federico Villarreal, Lima, Peru) for their technical assistance in the field phase of this study.

This study was supported in part by Grants-in-aid for Scientific Research from the Ministry of Education, Science, Culture and Sports of Japan (Grant Nos. 18256004 and 21780276). 


\section{References}

Aransay, A.M., Scoulica, E., Chaniotis, B., Tselentis, Y., 1999. Typing of sand flies from Greece and Cyprus by DNA polymorphism of 18S rRNA gene. Insect Mol. Biol. 8, 179-184.

Bates, P.A., 2007. Transmission of Leishmania metacyclic promastigotes by phlebotomine sand flies. Int. J. Parasitol. 37, 1097-1106.

Beati, L., Caceres, A.G.., Lee, J.A., Munstermann, L.E., 2004. Systematic relationships among Lutzomyia sand flies (Diptera: Psychodidae) of Peru and Colombia based on the analysis of $12 \mathrm{~S}$ and $28 \mathrm{~S}$ ribosomal DNA sequences. Int. J. Parasitol. 34, 225-234.

Caceres, A.G., Galati, E.A.B., 2001. Lista de Phlebotominae (Diptera: Psychodidae) para el Perú y especies consideradas como vectores naturales e incriminadas en la transmisión de patógenos de la Leishmaniosis Tegumentaria y la Enfermedad de Carrión (verruga peruana). Rev. Perú. Med. Exp. Salud Publica 18, 100-106.

Caceres, A.G., Villaseca, P., Dujardin, J.C., Bañuls, A.L., Inga, R., Lopez, M., Arana, M., Le Ray, D., Arevalo, J., 2004. Epidemiology of Andean cutaneous leishmaniasis: incrimination of Lutzomyia ayacuchensis (Diptera: psychodidae) as a vector of Leishmania in geographically isolated, upland valleys of Peru. Am. J. Trop. Med. Hyg. 70, 607-612.

Cohnstaedt, L.W., Beati, L., Caceres, A.G., Ferro, C., Munstermann, L.E., 2011. Phylogenetics of the phlebotomine sand fly group Verrucarum (Diptera: Psychodidae: Lutzomyia). Am. J. Trop. Med. Hyg. 84, 913-922.

Davies, C.R., Fernandez, M., Paz, L., Roncal, N., Llanos-Cuentas, A., 1993. Lutzomyia verrucarum can transmit Leishmania peruviana, the aetiological agent of 
Andean cutaneous leishmaniasis. Trans. R. Soc. Trop. Med. Hyg. 87, 603-606.

Kato, H., Cáceres, A.G., Gomez, E.A., Mimori, T., Uezato, H., Marco, J.D., Barroso, P.A., Iwata, H., Hashiguchi, Y., 2008. Molecular mass screening to incriminate sand fly vectors of Andean-type cutaneous leishmaniasis in Ecuador and Peru. Am. J. Trop. Med. Hyg. 79, 719-721.

Kato, H., Cáceres, A.G., Mimori, T., Ishimaru, Y., Sayed, A.S., Fujita, M., Iwata, H., Uezato, H., Velez, L.N., Gomez, E.A., Hashiguchi, Y., 2010b. Use of FTA cards for direct sampling of patients' lesions in the ecological study of cutaneous leishmaniasis. J. Clin. Microbiol. 48, 3661-3665.

Kato, H., Gomez, E.A., Cáceres, A.G., Uezato, H., Mimori, T., Hashiguchi, Y., 2010a. Molecular epidemiology for vector research on leishmaniasis. Int. J. Environ. Res. Public Health. 7, 814-826.

Kato, H., Gomez, E.A., Cáceres, A.G., Vargas, F., Mimori, T., Yamamoto, K., Iwata, H., Korenaga, M., Velez, L., Hashiguchi, Y., 2011. Natural infections of man-biting sand flies by Leishmania and Trypanosoma species in the northern Peruvian Andes. Vector Borne Zoonotic Dis. 11, 515-521.

Kato, H., Uezato, H., Gomez, E.A., Terayama, Y., Calvopiña, M., Iwata, H., Hashiguchi, Y., 2007. Establishment of a mass screening method of sand fly vectors for Leishmania infection by molecular biological methods. Am. J. Trop. Med. Hyg. 77, 324-329.

Kuwahara, K., Kato, H., Gomez, E.A., Uezato, H., Mimori, T., Yamamoto, Y., Calvopiña, M., Cáceres, A.G., Iwata, H., Hashiguchi, Y., 2009. Genetic diversity of ribosomal RNA internal transcribed spacer sequences in Lutzomyia species from areas endemic for New World cutaneous leishmaniasis. Acta Trop. 112, 131-136. 
Lucas, C.M., Franke, E.D., Cachay, M.I., Tejada, A., Cruz, M.E., Kreutzer, R.D., Barker, D.C., McCann, S.H., Watts, D.M., 1998. Geographic distribution and clinical description of leishmaniasis cases in Peru. Am. J. Trop. Med. Hyg. 59, 312-317.

Munstermann, L.E., 2004. Phlebotomine sand flies, the Psychodidae. In: Marquardt, W.C., Black, W.C., Freier, J.E., Hagedorn, H.H., Hemingway, J., Higgs, S., James, A.A., Kondratieff, B., Moore, C. G. (Eds.), Biology of Disease Vectors, 2nd ed. Elsevier, San Diego, pp.141-151.

Perez, J.E., Ogusuku, E., Inga, R., Lopez, M., Monje, J., Paz, L., Nieto, E., Arevalo, J., Guerra, H., 1994. Natural Leishmania infection of Lutzomyia spp. in Peru. Trans. R. Soc. Trop. Med. Hyg. 88, 161-164.

Perez, J.E., Veland, N., Espinosa, D., Torres, K., Ogusuku, E., Llanos-Cuentas, A., Gamboa, D., Arévalo, J., 2007. Isolation and molecular identification of Leishmania (Viannia) peruviana from naturally infected Lutzomyia peruensis (Diptera: Psychodidae) in the Peruvian Andes. Mem. Inst. Oswaldo Cruz. 102, 655-658.

Perez, J.E., Villaseca, P., Caceres, A., Lopez, M., Zolessi, A., Campos, M., Guerra, H., Llanos-Cuentas, A., 1991. Leishmania (Viannia) peruviana isolated from the sandfly Lutzomyia peruensis (Diptera: Psychodidae) and a sentinel hamster in the Huayllacallán Valley, Ancash, Peru. Trans. R. Soc. Trop. Med. Hyg. 85, 60.

Tamura, K., Dudley, J., Nei, M., Kumar, S., 2007. MEGA4: Molecular Evolutionary Genetics Analysis (MEGA) software version 4.0. Mol. Biol. Evol. 24, 1596-1599.

Terayama, Y., Kato, H., Gomez, E.A., Uezato, H., Calvopiña, M., Iwata, H., Hashiguchi, Y., 2008. Molecular typing of sand fly species (Diptera, Psychodidae, Phlebotominae) from areas endemic for Leishmaniasis in Ecuador by PCR-RFLP of 
18S ribosomal RNA gene. J. Vet. Med. Sci. 70, 907-913.

Thompson, J.D., Higgins, D.G., Gibson, T.J., 1994. CLUSTAL W: Improving the sensitivity of progressive multiple sequence alignment through sequence weighting, position-specific gap penalties and weight matrix choice. Nucleic Acids Res. 22, 4673-4680.

Torgerson, D.G., Lampo, M., Velazquez, Y., Woo, P.T., 2003. Genetic relationships among some species groups within the genus Lutzomyia (Diptera: Psychodidae). Am. J. Trop. Med. Hyg. 69, 484-493.

Young, D.G., Duncan, M.A. 1994. Guide to the Identification and Geographic Distribution of Lutzomyia Sand Flies in Mexico, the West Indies, Central and South America (Diptera: Psychodidae), Memoirs of the American Entomological Institute, vol. 54, Associated Publishers-American Entomological Institute, Gainsville, FL. 


\section{Figure Legends}

Fig. 1. Map of Peru showing the geographic locations where sand flies were collected along with the respective species and numbers (in parentheses) examined in this study. The numbers represent the following locations: 1. San Ignacio, 2. Coro Alto, 3. La Capilla, 4. Chota, 5. San Miguel, and 6. Santa Cruz de Toledo, Department of Cajamarca; 7. Chanchamayo, 8. La Cuesta, Nambuque and Padregual, Department of La Libertad; 9. Tarapoto, Department of San Martin; 10. San Pedro de Chonta, Department of Huanuco; 11. Colcap Bajo, Curcuy, Huanchoc, Atocshay and Pucuhuayllan, Department of Ancash; 12. Ambar, Jalcan and Huacan, Department of Lima; 13. Higosniyocc and 14. Pullo, Department of Ayacucho; 15. Ocobamba and 16. Maranura, Department of Cusco. $\quad$ Cab, Lutzomyia (Lu.) caballeroi; Cas, Lu. castanea; Mun, Lu. munaypata; Nog, Lu. noguchii; Nun, Lu. nuneztovari; Aya, Lu. ayacuchensis; Per, Lu. peruensis; Nev, Lu. nevesi; Rob, Lu. robusta; Mar, Lu. maranonensis; Ver, Lu. verrucarum; Tej, Lu. tejadai; Wph, Warileya phlebotomanica. Adapted from a map available at http://english.freemap.jp/.

Fig. 2. Phylogenetic tree of $18 \mathrm{~S}$ rRNA gene sequences among sand fly species. The 18S rRNA genes of 13 species were amplified from morphologically identified sand fly samples, and sequenced. The scale bar represents $0.005 \%$ divergence. Bootstrap values are shown above branches.

Fig. 3. PCR-RFLP analyses of $18 \mathrm{~S}$ rRNA genes from 13 sand fly species in Peru. (A) Schematic representation for genotyping of 13 sand fly species by PCR-RFLP of 
18S rRNA genes. The restriction enzymes used for classification are shown above branches. (B)-(E) PCR amplification was performed with sand fly $18 \mathrm{~S}$ rRNA gene-specific primers, and the PCR products were digested with (B) AfaI, (C) HapII, (D) KpnI and (E) XspI. Cab, Lutzomyia (Lu.) caballeroi; Cas, Lu. castanea; Mun, Lu. munaypata; Nog, Lu. noguchii; Nun, Lu. nuneztovari; Aya, Lu. ayacuchensis; Per, Lu. peruensis; Nev, Lu. nevesi; Rob, Lu. robusta; Mar, Lu. maranonensis; Ver, Lu. verrucarum; Tej, Lu. tejadai; Wph, Warileya phlebotomanica. 


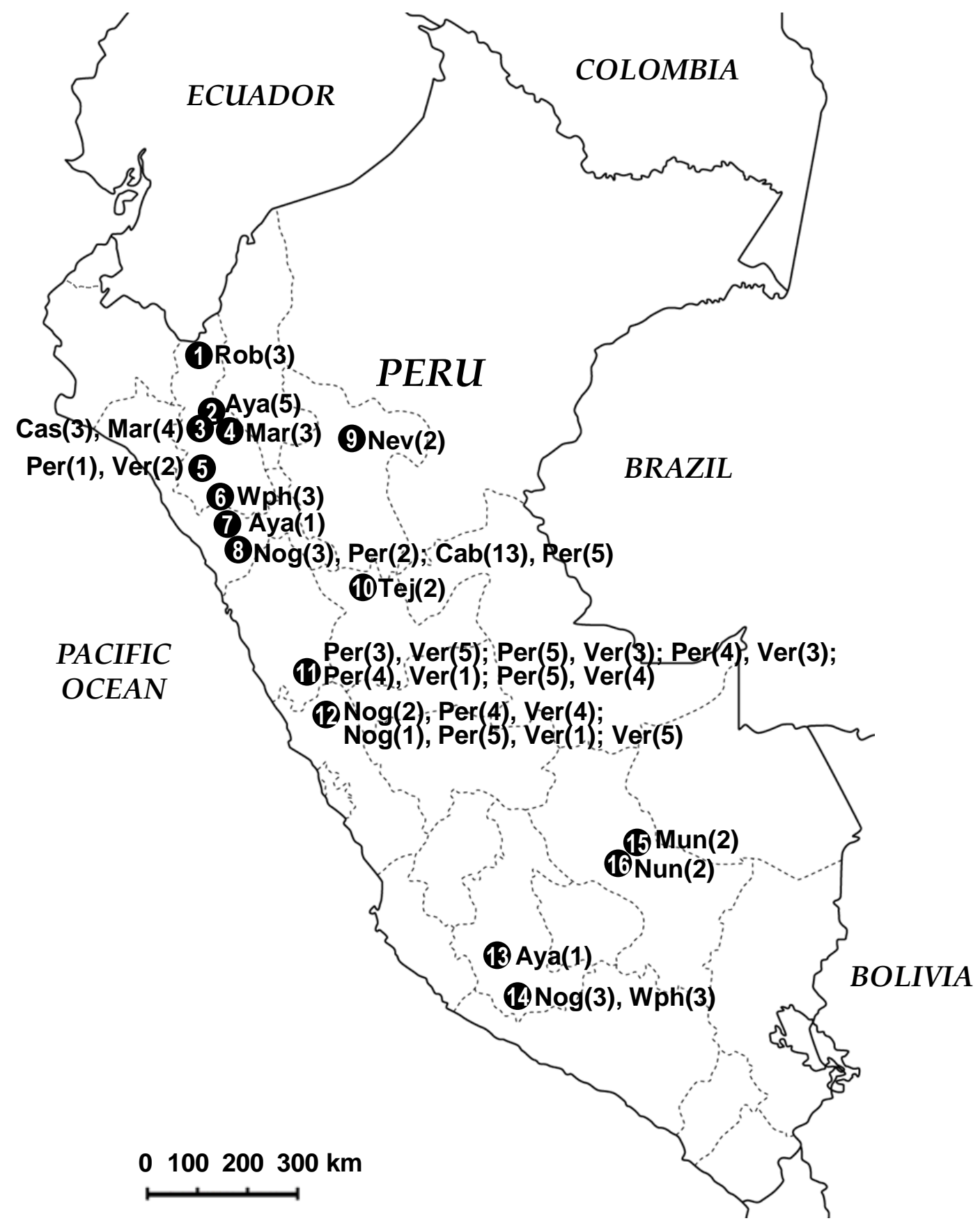

Fig. 1 
Subgenera,

Species group

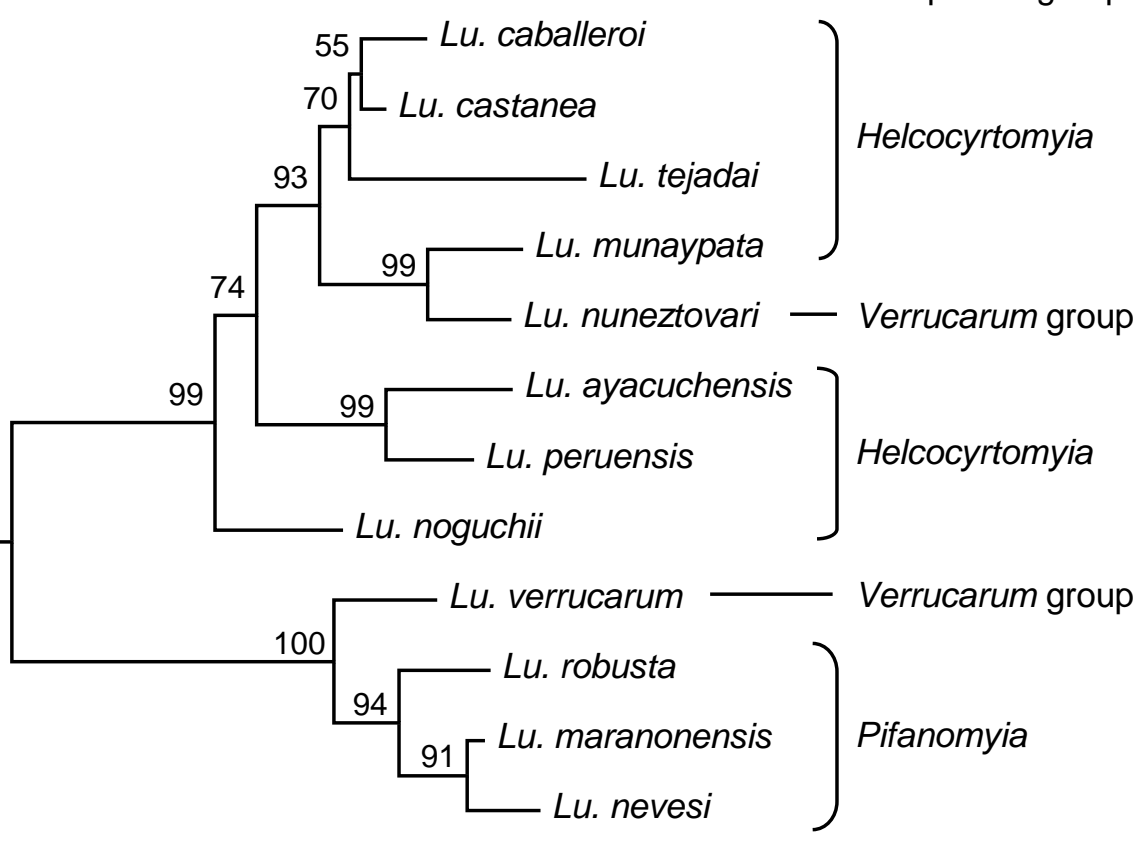

Warileya phlebotomanica

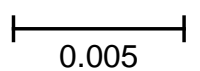

Fig. 2 
A

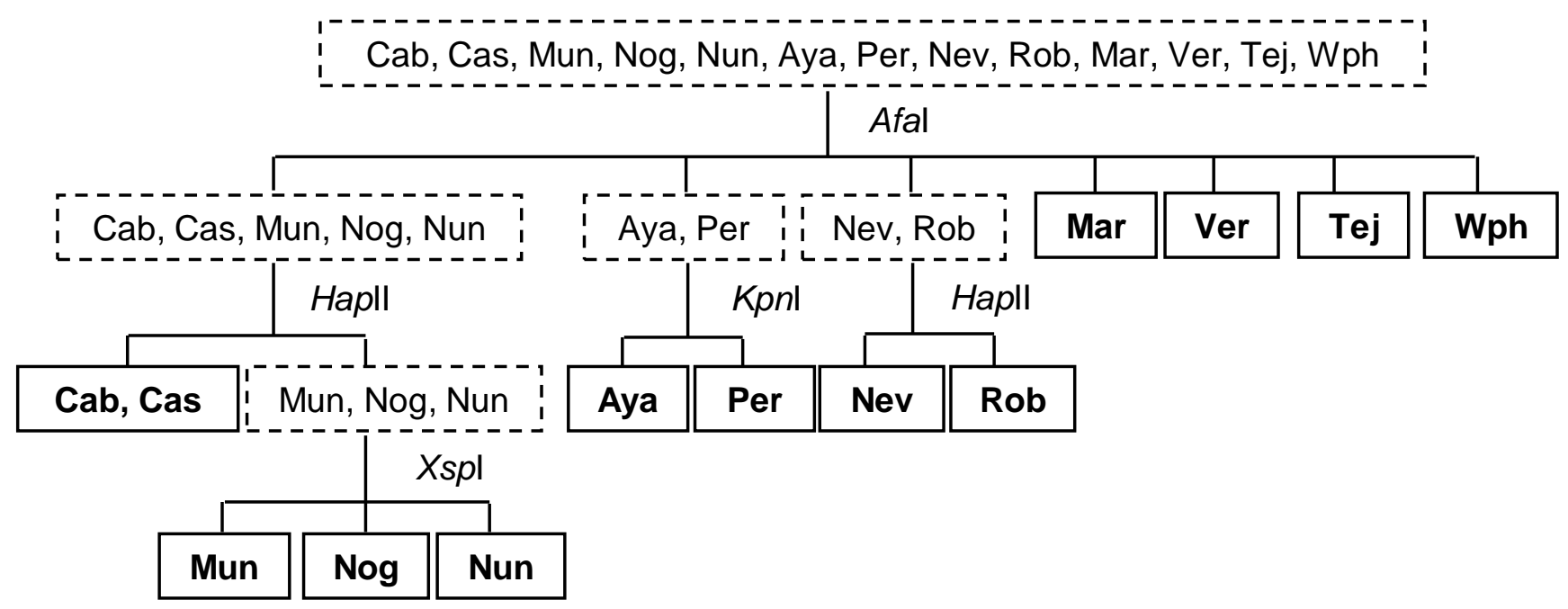

B

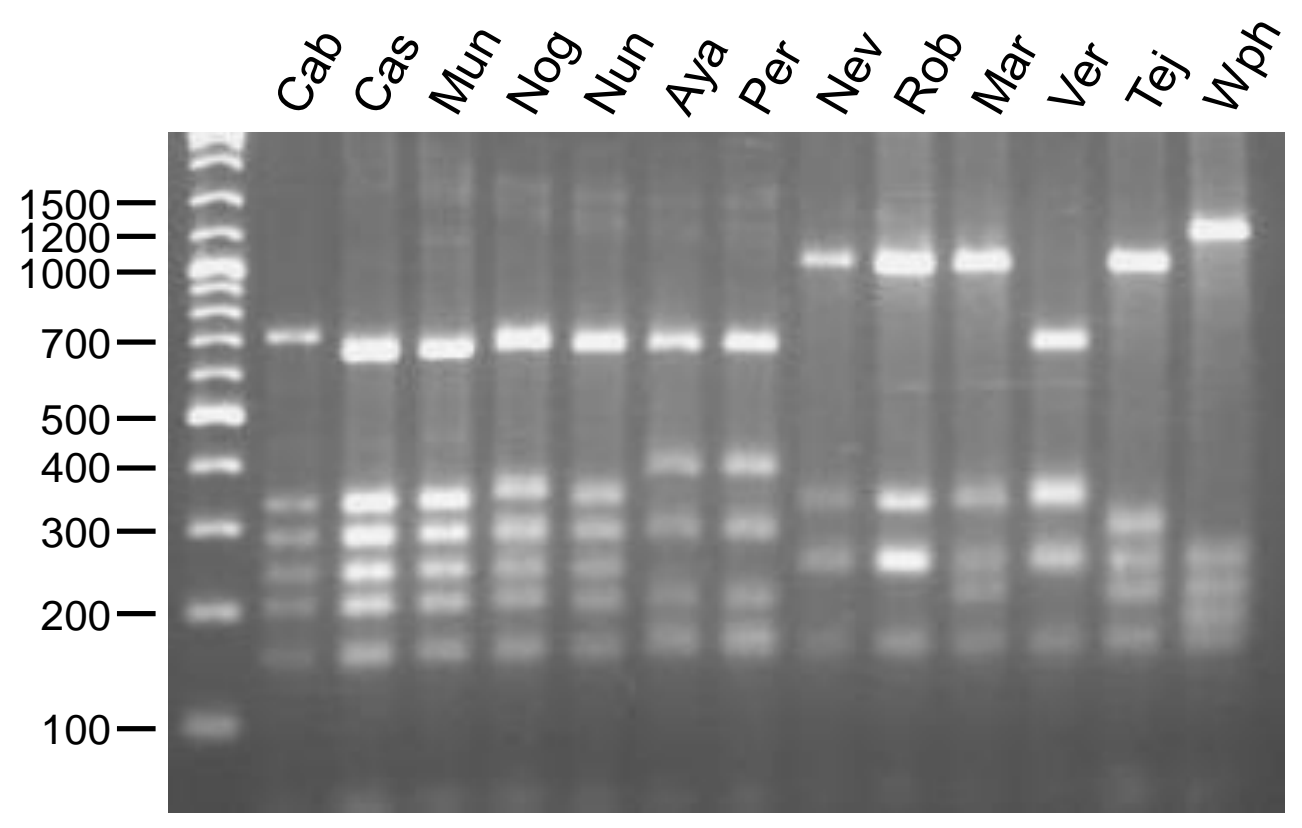

Fig. 3 
C

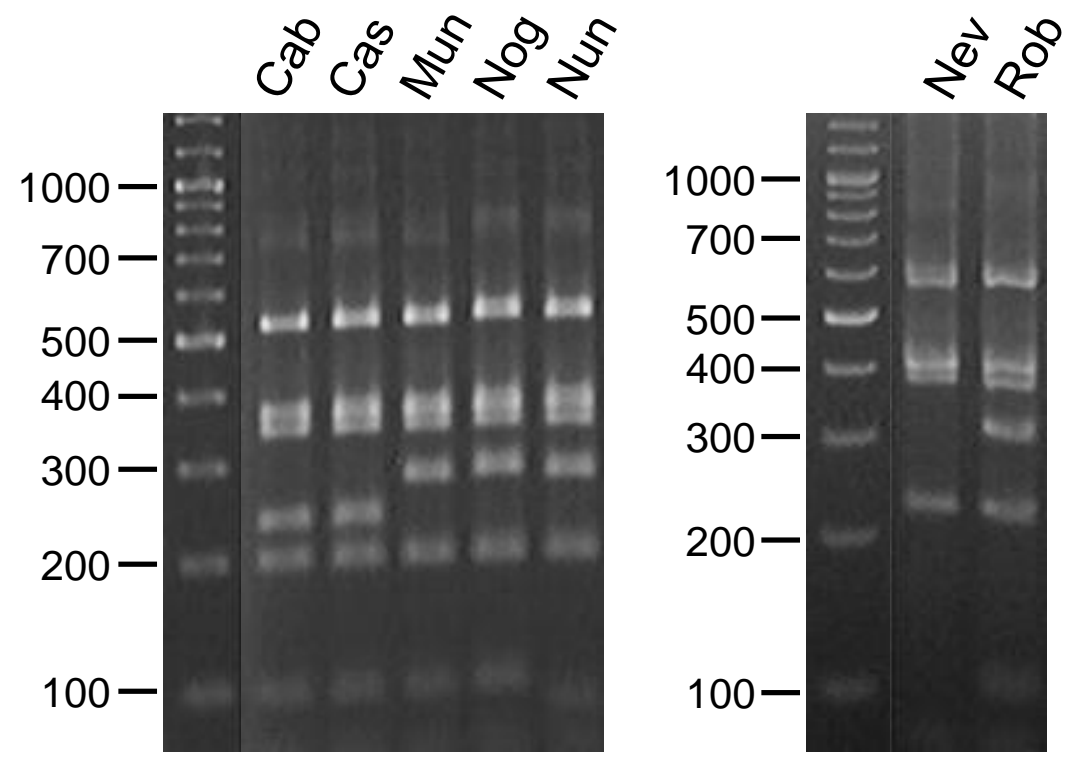

D

E
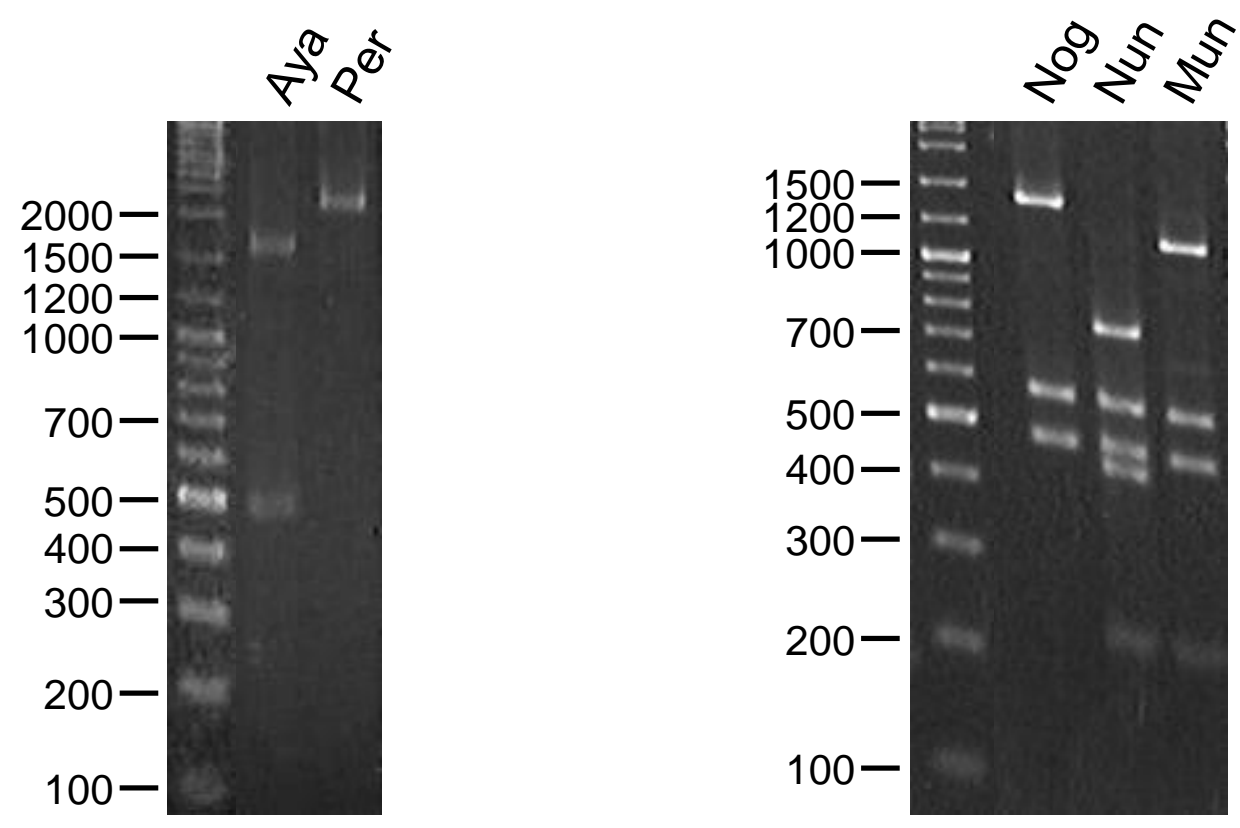

Fig. 3 
Table 1. Genotyping of sand flies in Andean areas of Peru

\begin{tabular}{lrrrrr}
\hline Locality & Ver & Per & Nog & Cab & Total \\
\hline Department of La Libertad & & & & & \\
$\quad$ Loma Grande & 8 & 12 & 0 & 0 & 20 \\
$\quad$ La Cuesta & 0 & 40 & 2 & 0 & 42 \\
Nambuque & 0 & 9 & 0 & 64 & 73 \\
$\quad$ Padregual & 74 & 0 & 40 & 114 \\
Department of Ancash & 31 & 11 & 0 & 0 & 42 \\
$\quad$ Atocshay & 124 & 2 & 0 & 0 & 126 \\
$\quad$ Colcap Bajo & 116 & 38 & 0 & 0 & 154 \\
$\quad$ Curcuy & 98 & 165 & 0 & 0 & 263 \\
$\quad$ Huanchoc & 13 & 8 & 0 & 0 & 21 \\
Pucuhuayllan & & & & & \\
Department of Lima & 214 & 142 & 4 & 0 & 360 \\
$\quad$ Ambar & 20 & 0 & 5 & 0 & 25 \\
$\quad$ Huarochiri & & & & & \\
\hline
\end{tabular}

Ver, Lu. verrucarum; Per, Lu. peruensis; Nog, Lu. noguchii; Cab, Lu. caballeroi 